Plant Protection and Quarantine. 2016. Issue 62.

UDC: $632.937+632.657$

A.M. KOVTUN, Post-Graduate Student, Institute of Plant Protection NAAS

\title{
ENTOMONEMATOLOGIC STUDIES OF THE AGROCENOSES OF UKRAINE AS A SOURCE OF IDENTIFICATION OF THE FACTORS OF THE POTENTIAL BIOCONTROL OF PLANT INSECTS
}

Various crops and long-term plantings in Ukraine (Zhytomyr, Kiev, Chernihiv, Khmelnytskyi and Vinnytsia Regions) have been observed for the purpose of identification of the natural centers of entomopathogenic nematodes (EPN) of the genera Steinernema and Heterorhabditis (Nematoda: Rhabditida) - the natural regulators of the number of harmful insects. The reasons and conditions, determining the nature of EPN distribution have been analyzed (Steinernema, Heterorhabditis). The results of the nematologic analysis of 206 soil samples (and traps) had showed that 27 (13.1\%) among them turned out to be positive concerning EPN. The conducted examinations of garden and field biocenoses have showed that they are occupied by entomopathogenic nematodes unevenly. On identification frequency, representatives steinernematidae representatives prevailed over heterorhabditis nematodes (55.6\% against $44.4 \%)$.

entomonemathologic inspections, entomopathogenic nematodes, genus Steinernema, genus Heterorhabditis, identification frequency, agrocenoses, plant protection, harmful insects

In modern conditions, the basis of the vast majority of the systems of crops protection against harmful organisms in the intensive systems of cultivation is based on the use of pesticides. It is impossible to call such line item logical in any way, considering that every day the ecological requirements to agricultural product production grow, and every time they force to put a question on the search of the most alternative methods of crops protection, promoting on the one hand - reduction of the pesticidal loading of agrobiocenosis, on the other hand - obtaining of the ecologically safe and high-quality products of the harvest [3]. Owing to it, the revival of the scientific researches, concerning the questions of enhancement of the biological methods of harmful organisms' control, in particular useful microbiota activization in agrophytocenosis on the basis of deeper under- 
standing of the specifics of interaction among harmful organisms and plants, and among harmful organisms and their super parasites, antagonists and predators, deserves attention [1]. Numerous achievements in the field of the theory and practice of biological protection against harmful organisms allowed fast increasing the amount of application of biological means in the systems of the integrated protection of crops.

In Ukraine the crops are damaged by about 400 types of insects, among of which a vast majority, both according to the quantity of types, and in the rate of harm (nearly $90 \%$ of all losses) are the representatives of various systematic genera and families of the class of insects - Insecta (type - Arthropoda). The most numerous insects-phytophages, damaging crops and plantings, include about 50 types. The special attention should be paid to larvae of click beetles, head-stander beetle, cereal chafer, carabus beetles, cockchafer, turnip moth caterpillar; flies - hessian, oscinella, phorbia fumigata, meromyza nigriventris; the group of sap-sucking phytophages aphids, also known as plant lice (The English Grain Aphid, (sitobion avenae, greenbug, or wheat aphid, barley aphid, the bird cherry-oat aphid) shieldbugs, aelias, field bugs, cereal and other types of trips; phyllotreta vittula, the cereal leaf beetle [2].

Recently, prompt development rates are reached by the special direction in the modern nematology, connected with the development of methods of the biological control of plant insects by means of nematodes - the parasites (pathogens) of insects, provoking nematode diseases (nematodoses) of the last ones. Nematodoses of insects considerably influence the dynamics of the number of populations both in the nature, and in the culture. In total more than 1 thousand of worms-parasites, parasitizing in the insects at all the stages of their development - from the egg to the imago, and concentrate in all the organs and tissues in the form of eggs, larvae or adult individuals [9].

For the biological protection of plants two sorts of entomopathogenic nematodes - Steinernema and Heterorhabditis (Nematoda: Rhabditida) have the greatest practical interest. Owing to the mutualistic (mutually advantageous) connection with intestinal symbiont bacteria of the genera Xenorhabdus spp. (characteristic of Steinernema spp.) and Photorhabdus spp. (characteristic of Heterorhabditis spp.) of Enterobacteriaceae family, steinernematidae and heterorhabditis representatives are capable to destroy insects and to develop in their corpses that allows using them as standard bioinsecticides [8]. The insects of more than 100 families from 21 series are infected by them, among which in the majority are: larvae of Lepidoptera, Coleoptera, Diptera, and also imaginal stages of Orthoptera, Homoptera and Hemiptera, etc.

The native habitat of EPN (Steinernema, Heterorhabditis) is the soil, therefore the greatest efficiency is reached in case of their against plant in- 
sects, whose development lifecycle is connected with the soil, for the most larvae of which the latent conduct of life in the upper layer of the ground is characteristic (larvae of click beetles, darkling beetles, comb-clawed beetles, scarab beetles, etc.). Protection of crops against the harmful insects, having soil stages in their development cycle, is an extremely complex challenge because of their capability to accumulate in case of permanent handlings, and also the limited availability to various observations of them, as a result of the latent conduct of life, unlike the insects, living on the surface of the ground. Until recently, one of the main methods of fighting against this ecological group of insects was - a chemical method, using toxic chemicals. However, all of them were extremely toxic not only for insects, the soil, plants, but also for people therefore, some of them, were unsuitable right after the corresponding control.

According to the forecasts of specialists in plant protection, in the closest future, one of the major places among the biological means for control of the number of plant insects will be occupied by the biological products on the basis of EPN sorts of Steinernema and Heterorhabditis. Till the middle of the 50s of the 20th century a large number of scientists all over the world did not pay to entomonematodes special attention, in comparison with other potential bioagents (bacteria, viruses, fungi, etc.). However, over time, this look began to change, and the set of the researches conducted by scientists in different countries of the world was shown that Entomopathogenic nematodes (Steinernema, Heterorhabditis) have those practical qualities, which provide a possibility of creation of biological medicines of a new generation on their basis. Now researches of this ecological group of nematodes are conducted more than in 100 laboratories of 60 countries of the world (the USA, Canada, Turkey, Germany, the Netherlands, Slovakia, Colombia, etc.), which develop and actively implement in production the medicines against many economically significant plant insects [4].

In Ukraine, the application of biological products on the basis of EPN in the systems of crops protection has not found the worthy reflection yet, the last ones are not used properly nowadays as well that is caused, by the lack of information and the lack of agriculture experts' initiative. Entomonematology - a young science, and not sufficiently studied in our country, even among biologists (in particular zoologists and helmintologists). Poor entomonematology development in Ukraine is caused, first of all, by the insufficient popularity of its prospects and opportunities among biologists, and also that is not less important, in considerable complexity of development of this special ecological group of worms, through their latent way of life, the rarity of their occurrence in the nature. By this time on the territory of Ukraine (including the Autonomous Republic of Crimea) three types of entomopathogenic nematodes from the genus Steinernema have been registered: $S$. carpocapsae, $S$. feltiae, $S$. arenarium and one typical sort from the 
genus Heterorhabditis $-H$. bacteriophora $[6,12,14]$. The essential efforts, directed at expansion of the researches on EPN (Steinernema, Heterorhabditis), directly lying on the scientists in the field of plant protection as well, and which quality, directly depends on the level of their scientific research in this direction, are necessary.

Considering the suppressing importance of this direction in plant protection and in the light of general greening of the agricultural industry, these objects are urgent, and require the detailed studying for the further development of the biological method of crops protection against plant insects. Searching of local (native) steinernema and heterorhabditis populations, because of their adaptation to the local climate, and also other biotic and abiotic regulatory factors should be considered the primary task. Using of the native high-pathogenic EPN isolates for cultivation of laboratory cultures or industrial cultivation perform the control of local harmful insects more effectively.

The purpose of researches - searching of the local EPN populations among the genera Steinernema and Heterorhabditis in the agrobiocenoses of Ukraine; determination of the features of their distribution, occurrence frequency.

The area, materials and methods of researches. For the purpose of identification of the natural populations of entomopathogenic nematodes (Steinernema, Heterorhabditis), in June-September, 2016 the route inspections of the crops and long-term plantings of various plants were carried out, selected soil samples in five areas of Ukraine - Chernihiv, Kiev, Zhytomyr, Vinnytsia and Khmelnytskyi were selected.

In Chernihiv region two areas were observed: Kozeletsk (Morivsk village, Oster town) and Chernihiv (Boromyky village). In total all over the district 34 soil samples were selected and 54 soil traps are pledged. In Kiev region, two districts were observed, namely: Baryshivka (Baryshivka town) and Borodyanka (Kozyntsi village). In Kiev Region, 41 samples were analyzed (25 soil samples and 16 soil traps). In Zhytomyr and Vinnytsia regions one district in each - Lyubartsi district (Bicheva village) and Khmelnytskyi district (Semki village) were observed. In total in Zhytomyr region 6 soil samples were selected, slightly more (22 soil samples) were selected in the agrocenoses of Vinnytsia region. And at last, in Khmelnytskyi region three areas among which: Volochyisk district (Ozhigovtsi, Bokiyevka villages) Teofipol district (Borshchivka village) and Gorodotsk district (Kumaniv village) were studied. In total 49 soil samples were selected all over the region.

The samples were selected from the crops: buckwheat, sugar beet, sunflower, oats, haricot, pumpkin, lucerne, potatoes, soy; from the plantings of the fruit gardens (drupes, pomes, berry and nut plants) and evergreen ornamental plants (a juniper, thuja). The samples were selected on the elementary area incidentally (from $4 \mathrm{~m}^{2} 5$ subsamples in different places were 
taken, forming one general sample from them), or systematically along the route by means of a usual manual spade. For the majority of field cultures soil samples were selected from the top layer of the ground profile (from the main zone of growth of the plant roots), up to the depth of $15-30 \mathrm{~cm}$. While examining tree plantings (orchards, decorative cultures), the samples were selected around the boles of the separate trees in the radius of $1 \mathrm{~m}$. up to the depth of $40 \mathrm{~cm}$. Soil samples were both pointed, and united (several samples from different points of selection from one typical site were mixed together) [13]. The volume of each sample made a little more than $300 \mathrm{~cm} 3$. The places of soil sampling and the coordinate of points of selection have been determined and fixed. The paper, with the fixed serial number and the date was added to each soil sample.

Except the direct selection of soil samples, for nematode infection determination in vivo the method of soil traps, or so-called "live trap" with the use of susceptible test insects (larvae of Galleria mellonella L.) was applied. G. mellonella larvae were cultivated in vitro on "bees remains" (old, damaged honeycombs) in 3-liter glass jars, which were placed in the thermostat with the working temperature of incubation of $27-30{ }^{\circ} \mathrm{C}$. The larvae of the last age stage (with the weight of $0.20 \pm 0.03 \mathrm{~g}$ ) by two individuals, were placed in the spherical capsules from the metal gauze and dug in to the soil on the depth up to $10 \mathrm{~cm}$. (in the radius of $1 \mathrm{~m}$. from the bole of the tree on the depth up to $20-30 \mathrm{~cm}$.) on the experimental garden, having designated the place of their stay. In 5-6 days, insects were taken out for the further analysis in vitro.

Along with soil samples and traps, collecting (catching) of potential soil insects EPN-hosts, which got to our field of vision in case of inspections, were carried out. All the insects, living in the soil were directly brought together manually. Generally, direct selections of 136 soil samples were made and 70 soil ("alive") traps are pledged, together constituted 206 samples.

In vitro for the purpose of EPN isolation soil samples the abiological test method was applied. For this purpose, the samples of the selected soil were carefully mixed, $300 \mathrm{~cm}$. i were taken, and filled in plastic glasses (if necessary the soil was humidified with settled tap water), and there 3-5 larvae of advanced age of Galleria mellonella L. were added. The glasses with the soil, in their turn, were tied with coarse calico round and placed on the pallet, being turned upside down. Each glass was signed (the date and the place of sampling) and left for the exposition for 5-6 days [10]. Every day the conditions of caterpillars were examined, the dead ones were taken away and replaced by new ones.

Isolation of the nematodes from died samples-insects with the accurate signs (symptoms) of nematode affection (color changing of the external membranes of the body, the sizes and the shape of the body, etc.) was performed by application of "a water trap" (Whyte's trap), or helminthological 
surgery with their subsequent careful observation under binocular MBS-9 was carried out. All discovered EPN isolates, stored separately in the form of water suspension in conic flasks in the refrigerator at the temperature of $4{ }^{\circ} \mathrm{C}$ of $0,001 \%$ formalin solution in the physiological salt solution [13].

Establishment of the patrimonial belonging of the isolated entomopathogens came down to the analysis of the appearance of the perished test-insects, in particular color changes of the outside body membranes of G. mellonella lavrae. The frequency of occurrence of the genera of entomopathogenic nematodes was determined as in the percentage rate, as the ratio of the number of samples, in which this genus came out, towards the total number of samples: $\mathrm{P}=\mathrm{n} / \mathrm{N}^{*} 100(\%)$, where $\mathrm{n}-$ the number of samples, in which this genus has been revealed; $\mathrm{N}-$ the total quantity of selected and studied samples.

Results of researches and their discussion. It is well-known that entomopathogenic types of nematodes of Steinernema and Heterorhabditis genera is a mandatory component of any biogeocenosis and can be met on all the continents except for the Antarctic and almost in all the latitudes and heights above sea level [11]. As for the frequency of detection of the entomopathogenic nematodes in different types of biocenoses, these data are rather contradictory. A part of researchers tends to the judgment that entomonematodes are more often observed in natural ecosystems, not changed under the influence of human activities. According to other researchers, entomopathogenic nematodes - the main inhabitants of agroecosystems. Also quite often they can be observed in plantings of trees on streets, sidewalks of the cities, etc. [7]. Numerous researches showed that EPN (Steinernema, Heterorhabditis) are non-uniformly wide-spread, and it is impossible to specify a certain set of the factors, allowing solving the problem of EPN distribution, connected with the type of the area or the level of area transformation, as a lot of biotic and abiotic factors of the environment influence EPN distribution, activity and pathogenicity. However, in one judgment the opinions of the scientists meet - entomopathogenic nematodes occupy both natural, and anthropogenous biocenoses.

Studying of different agroecosystems and assessment of natural regulatory agrobiocenosis factors, including detection of the natural EPN centers of the genera Steinernema and Heterorhabditis, is one of the key stages for the successful development of the integrated protection of agricultural plants. In the agrobiocenoses, which are provided by crops and cultural plants with all the community of all the inhabiting organisms, all the completeness of the intraspecific and interspecies relations, including predatoriness, parasitism and antagonism, which directly are the cornerstone of the biomethod, is carried out [1].

As a result of the conducted researches it has been established that among 206 analyzed samples, 27 (13.1\%) were positive in relation to EPN 
from Steinernema and Heterorhabditis genera (fig). The appearance of the analyzed perished test-insects gave the grounds to consider that, in the samples, except the nematode infection, other entomopathogenic microorganisms were presented as well (bacteria, viruses, fungi, etc.) which, perhaps, caused the mortality of test insects, however, were not studied, therefore directly did not concern our research. The main points of revealing of the entomopathogenic nematodes (Steinernema, Heterorhabditis) were concentrated in Chernihiv Region (Morovsk village, Oster town, Kozeletsk district, the village of Boromyki, Chernihiv district) and Kiev Region (Baryshivka town, Baryshivka district). The soil samples, selected in Zhytomyr, Vinnytsia and Khmelnytskyi regions, did not contain EPN.

Generally the occurrence frequency of EPN was higher in the plantings of evergreen decorative cultures (juniper, thuja) $-75 \%$, than in the old fruit gardens, provided stone fruits, seed, berry and nut plants $-31.3 \%$ and field agrocenoses (buckwheat, sunflower, haricot, pumpkin) $-12.5 \%$.

The representatives of steinernematides prevailed over heterorhabditis nematodes $-15(55.6 \%)$ and $12(44.4 \%)$ positive samples respectively. The similar tendency remains practically in each country of the world where ecological and faunistic examinations of EPN (Steinernema, Heterorhabditis) were conducted.

Only the samples, selected from fruit plantings (mulberry, apricot, plum, apple-tree, walnut tree) and evergreen decorative cultures (thuja) were positive relatively heterorhabditis nematodes, they have not been revealed in field grounds. It should be noted that the population indicator of
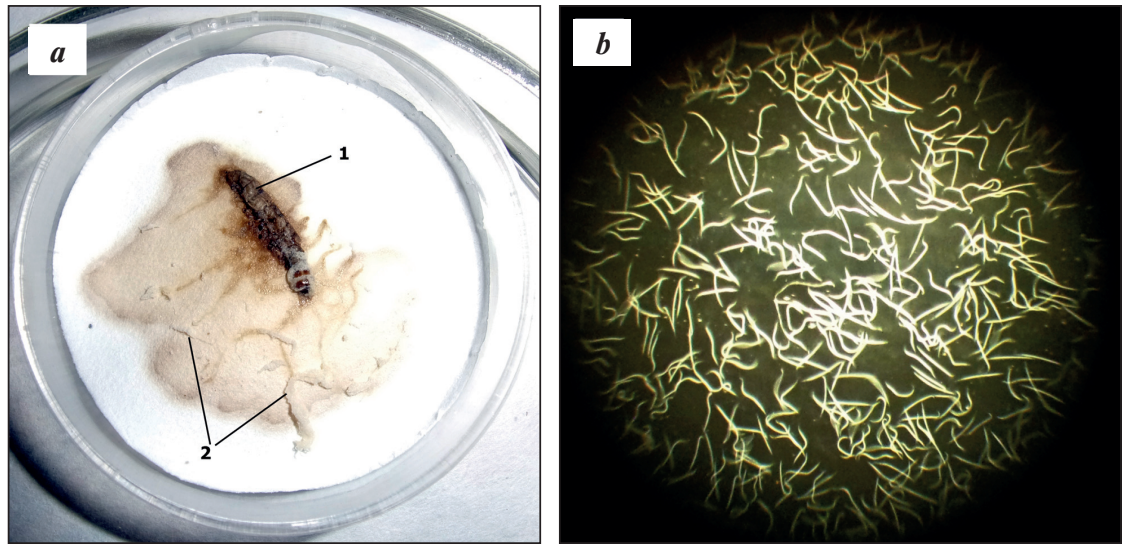

Fig. a - isolation of invasive EPN larvae by means of the method of "water trap" (Whyte's trap); b - the general appearance of the invasive larvae (IL) in the water density. Symbols: 1 - died insect-host (Galleria mellonella L.), 2 - IL migration from the rests of G. mellonella's body towards water (positive hydrotropism) (orig.). 
EPN was higher than the soil samples, which have been selected in field cenoses of Kiev region almost by 2.5 times, than in Chernihiv region (28.5\% against $10.5 \%$ ), and also is 4.5 times higher in fruit plantings (60\% against 12.9\%). In Chernihiv Region the representatives of the sort Steinernema prevailed unlike Kiev Region, in which there were nematodes from the sort Heterorhabditis more often.

The alternative to soil samples is collecting (catching) of potential insects EPN-hosts. In spite of the fact that the first EPN finds had been obtained from died insects, subsequently it turned out that in natural populations of insects the level of infection is not such high. In the nature, the chances to find insects naturally affected by the nematode infection are made by less than $3 \%$ if only there is no large-scale epidemic (epizootic) or big selection of insects [5]. So, collected by us under natural conditions, the analysis of potential ground-living insects EPN-hosts - the larvae of click beetles (spring beetles) and larvae of the scarab beetles (melolonthinae), regarding their infection with the entomopathogenic nematodes did not reveal any invasion in them. Other entomopathogenic organisms (bacteria, viruses, fungi, etc.) which, perhaps, caused the death rate of insects, have not been studied.

\section{CONCLUSIONS}

Thus, the results of researches testify about a quite considerable population of the agrocenoses of Ukraine, consisting of nematodes-pathogens of insects from the genera Steinernema and Heterorhabditis. From the soil samples, which have been selected in five areas (and soil traps) 5 EPN strains are marked out (the village of Morovsk, Oster town, Kozeletsk district, village of Boromyki, Chernihiv district, Chernihiv Region. and Baryshivka town, Baryshivka district, Kiev Region). EPN distribution and patrimonial variety depended both on the shape of the forming plant look (edificator) in agrophitocenosis, and on the extent of the anthropogenous transformation of the area. The representatives of the sort Steinernema preferred field cultures, unlike the nematodes from the sort Heterorhabditis, which were more often allocated from garden cenoses and plantings of decorative cultures. Taken from the nature the microscopic analysis of the potential insects EPN-hosts, living in the ground has not revealed entomopathogenes in them.

We consider an important stage of our further researches conducting the corresponding laboratory and field experiments, according to biopotentials of the revealed local isolates steinernematides and heterorhabditis nematodes against plant insects.

\section{BIBLIOGRAPHIC LIST}

1. Біологічний захист рослин / М.П. Дядечко, М.М. Падій, В.С. Шелестова та ін.; за ред. М.П. Дядечка та М.М. Падія. - Біла Церква: НТПЇ БДАУ, 2001. - 312 с. 
2. Борзих О.I. Комплекс шкідливої біоти в агроекосистемах України // Захист і карантин рослин, 2015. - Вип. 61. - С. 3-10.

3. Довідник із захисту рослин / Л.Іे. Бублик, Г.Іे. Васечко, В.П. Васильєв та ін.; за ред. М.П. Лісового. - К.: Урожай, 1999. - 744 с.

4. Ед Люїс. Сучасний стан та перспективи застосування ентомопатогенних нематод / Ед Люїс, Херри Кайа, Т.Р. Стефановська, В.В. Підліснюк // Вісник Кременчуцького державного політехнічного університету імені Михайла Остроградського. - 2009. - Вип. 4 (57). Частина $2-$ C. $141-153$.

5. Злотин А.3. Техническая энтомология / А.З. Злотин. - К.: Наукова думка, 1989. - 183 с.

6. Сигарева Д.Д. Распространение энтомопатогенных нематод семейств Steinernematidae и Heterorhabditidae на территории Украины / Д.Д. Сигарева, В.В. Олененко, Н.В. Грацианова // Нематоды естеств. и трансформир. экосистем / Ин-т биологии Карел. науч. центра РАН [и др.]. - Петрозаводск, 2011. - С. 92-93.

7. Сігарьова Д.Д. Поширення ентомопатогенних нематод родин Steinernematidae та Heterorhabditidae в біоценозах України / Д.Д. Сігарьова, В.В. Олененко, Н.В. Грацианова, Є.Б. Яковлєв // XIV конференція Українського наукового товариства паразитологів (Ужгород, 21-24 вересня, 2009 р.): тези доповідей. - Київ, 2009. C. 101.

8. Спиридонов С.Э. Применение энтомопатогенных нематод в защите растений / Прикладная нематология. Под ред. Н.Н. Буторина, С.В. Зиновьева, О.А. Кулинич и др. - М.: Наука, 2006. - С. 291-324.

9. Спиридонов С.Э. Энтомопаразитические и энтомопатогенные нематоды / Патогены насекомых: структурные и функциональные аспекты / Под ред. В.В. Глупова. - М.: Круглый год, 2001. - С. 428474.

10. Яковлєв С.Б. Методи вивчення ентомопатогенних нематод / Є. Б. Яковлєв, В. О. Харченко // Вісн. Київ. нац. ун-ту ім. Т. Шевченка. Біологія. - 2015. - Вип. 3 (68) - С. 51-54.

11. Hominick W.M. Biogeography / W.M. Hominick // Entomopathogenic nematology; ed. R. Gaugler. - Wallingford, UK: CABI Publishing. 2002. - P. 115-143.

12. Kharchenko $V$. Study of entomopathogenic nematodes from genera Steinernema and Heterorhabditis in Ukraine / V. Kharchenko, D. Sigareva, T. Galagan, V. Olenenko // Abstracts of the XI European Multicolloquium of Parasitology. Cluj-Napoca, July 25-29, 2012. P. 506-507.

13. Orozco R.A. Soil sampling and isolation of entomopathogenic nematodes (Steinernematidae, Heterorhabditidae) / R.A. Orozco, M.M. Lee, S.P. Stock. // Journal of visualized experiments. (89). - 2014. - P. 1-8. 14. Yakovlev Ye. B. Findings of entomopathogenic nematodes (Rhab- 
ditida, Steinernematidae) in nature reserves in Ukraine / Ye. B. Yakovlev, V.A. Kharchenko, Z. Mraček // Vestnik zoologii. - 48 (3). - 2014. P. 203-210.

Ковтун А.М. Ентомонематологічні обстеження агроценозів України - як джерело виявлення чинників потенційного біоконтролю комах-шкідників

Обстежено різноманітні посіви та багаторічні насадження сільськогосподарських культур в Україні (Житомирська, Київська, Чернігівська, Хмельницька та Вінницька обл.), з метою виявлення природних осередків ентомопатогенних нематод (ЕПН) родів Steinernema ma Heterorhabditis (Nematoda: Rhabditida) - природних регуляторів чисельності шкідливих комах. Проаналізовано причини і умови, що визначають характер поширення ЕПН (Steinernema, Heterorhabditis). Результати нематологічного аналізу 206 грунтових проб (і пасток) засвідчили, що $27(13,1 \%)$ з них виявились позитивними відносно ЕПН. Проведені обстеження садових та польових біоценозів показали, що вони заселені ентомопатогенними нематодами нерівномірно. За частотою виявлення, переважали представники стейнернематид над гетерорабдитидами (55,6\% проти 44,4\%).

\section{Ковтун А.Н. Ентомонематологические обследования агроценозов Украины - как источник виявления факторов потенциального биоконтроля насекомых-вредителей}

Обследовано различные посевы и многолетние насаждения сельскохозяйственных культур в Украине (Житомирская, Киевская, Черниговская, Хмельницкая и Винницкая обл.), с целью выявления природных очагов энтомопатогенных нематод (ЕПН) родов Steinernema u Heterorhabditis (Nematoda: Rhabditida) - природных регуляторов численности вредных насекомых. Проанализированы причины и условия, определяющие характер распространения ЕПН (Steinernema, Heterorhabditis). Результаты нематологического анализа 206 почвенных проб (и ловушек) показали, что $27(13,1 \%)$ из них, оказались положительными относительно ЕПН. Проведенные обследования садовых и полевых биоценозов показали, что они заселены энтомопатогенными нематодами неравномерно. По частоте выявления, преобладали представители стейнернематид над гетерорабдитидамы (55,6\% против 44,4\%). 